\title{
Fikih Siyasah dan Tantangan Pendidikan Multikultal
}

\author{
Irham Fathiyyah Shulha
}

\begin{abstract}
The study of looking for a good educational format in a multicultural country like Indonesia will continue to be interesting, because it will experience a number of challenges to be faced. In addition to the challenges of multicultural education in terms of concepts, challenges will also arise in the perspective of the Siyasah Jurisprudence which is interpreted in the Islamic political order because in Indonesia the majority of the population is Muslim. This scientific work aims to answer the problem formulation of the challenges of multicultural education both in terms of concepts and from the point of view of pandanus fiqh siyasah (Islamic politics). The method used in this research is a descriptive research library with a rationalistic qualitative research analysis. The challenge of multicultural education will be the rejection of a group of Muslims who have not fully understood the meaning of multiculturalism. They think that the concept of Multicultural Education that has been initiated is wrong. In the viewpoint of fiqh siyasah, the challenge of multicultural education is in terms of regulations that have no specific legal umbrella governing the concept of multicultural education oriented to Maqoshidu As-Syari'ah.
\end{abstract}

Keywords: Fiqh siyasah, multicultural education

\section{Pendahuluan}

Ikhtiar untuk mencari dan mendapatkan konsep pendidikan Islam tidak akan pernah berhenti walau zaman telah berganti. Upaya itu akan terus menerus dilakukan penyempurnaan seiring dengan perubahan, perkembangan dan dinamika masyarakat. Pemikiran untuk mencari konsep pendidikan Islam tidaklah bersifat reaktif dan sementara yang hanya menjawab dan membela kebenaran setelah problema muncul di permukaan.Upaya itu, selain harus mampu membuat dan merumuskan konsep yang dapat dioperasionalkan, juga harus mengandung nilai dasar yang bersifat universal, strategis, proaktif dan antisipatif, serta adaptatif terhadap berbagai kebutuhan dan perkembangan masyarakat, bahkan harus mendahului perkembangan masalah yang akan muncul pada masa yang akan datang. Selain itu juga harus mampu mempertahankan nilai dasaryang paling benar dan diyakini eksistensi kebenarannya (Mastuhu, 1999). 
Untuk menemukan konsep pendidikan Islam, agar mampu memberi respon terhadap berbagai problema dan tantangan era globalisasi ini sangat diperlukan evaluasi dengan melihat faktor yang bersifat internal dan eksternal. Secara internal, dunia pendidikan Islam di Indonesia masih diperhadapkan berbagai problema yang tidak ringan dan gampang diselesaikan secara instan, tetapi memerlukan kajian, studi dan pemikiran yang lebih komprehensif, serta multidimensi (Ihsan, 1997). Komponen pendidikan tersebut meliputi: visi, misi, tujuan pendidikan, kurikulum, kompetensi profesionalisme guru, metodologi pembelajaran, kompetensi lulusan, sarana dan prasarana, pengelolaan, pembiayaan, evaluasi, dan termasuk peserta didik dan lingkungan pendidikan yang saling terkait (Kemdikbud, n.d.).

Pengimplementasian sikap Multikulturalisme dalam Pendidikan Agama Islam di lembaga pendidikan (meliputi kompetensi dan profesionalisme guru) menjadi sangat penting. Berdasarkan latar belakang pokok permasalahan penelitian ini adalah bagaimana tantangan Pendidikan Multikultural dalam Fikih Siyasah ? sehingga peserta didik dapat mengembangkan sikap menghargai nilai kemanusiaan, menerima perbedaan dan kesamaan.

\section{Metode}

Metode penelitian karya tulis ilmiah ini bersifat kualitatif dengan menggunakan metode penelitian kepustakaan (library reseach). Yang dimaksud dengan penelitian kepustakaan adalah penelitian yang dilakukan hanya berdasarkan atas karya tertulis, termasuk hasil penelitian baik yang telah maupun yang belum dipublikasikan. Penelitian kepustakaan merupakan jenis penelitian kualitiatif yang padda umumnya tidak terjun ke lapangan dalam pencarian sumber datanya. Penelitian kepustakaan merupakan metode yang digunakan dalam pencarian data atau cara pengamatan (bentuk observasi) secara mendalam terhadap tema yang diteliti untuk menemukan jawaban sementara dari masalah yang ditemukan di awal sebelum penelitian ditindaklanjuti. (Arikunto, 1998), (Zed, 2008)

\section{Hasil dan Pembahasan}

Pendidikan Agama Islam yang diajarkan di Madrasah/Sekolah pada umumnya juga belum mengajarkan sepenuhnya pendidikan multikultural yang baik, bahkan cenderung berlawanan. Akibatnya, konflik sosial dengan legitimasi keagamaan yang diajarkan dalam pendidikan agama di lembaga pendidikan menjadi salahsatu latar belakangnya. Pengajaran Agama Islam yang tidak komprehensif tidak akan mampu menanggulangi keragaman yang ada, justru akan menajdi sumber konflik. Keragaman pada awalnya memang tidak menimbulkan persoalan atau gejolak sosial. Akan tetapi, dikarenakan motif ekonomi, politik, dan sosial manusia yang sering dibarengi dengan keinginan 
untuk menguasai, sering menjadikan mereka menghalalkan segala cara. Yang pada akahirnya manusia malah menggunakan naluri hewaniah ketimbang akal sehat dan hati nuraninya dakam melakukan sebuah tindakan. (Fanani, 2004).

Realitas menunjukkan bahwa Pendidikan Agama Islam jauh dari apa yang diharapkan dari pendidikan yaitu memperhatikan perkembangan akal sehat, jasmani, hati dan rohani peserta didik. Demikian juga, pendidikan yang dipraktikkan lebih bercorak eksklusif, yaitu seakan-akan hanya agamanya sendiri yang benar, mazhab atau aliran teologinya saja bisa diterima dan mempunyai hak hidup, sementara agama yang lain salah, mazhab dan aliran pemikiran orang lain harus ditolak, tersesat dan terancam hak hidupnya, baik di kalangan mayoritas maupun minoritas. Padahal, nilai keluhuran dan kemanusiaan yang lahir dari pendidikan terwujud ketika diperhadapkan dengan realitas multikultural, yaitu sebuah sikap yang menghargai perbedaan dan keanekaragaman. disertai dengan kearifan menerima dan mengakui kebeneran yang ada pada orang lain. Sebuah sikap multikultural dalam beragama sebuah keniscayaan yang mesti dilakukan dalam kehidupan seharihari.

Salah satu aspek penting untuk mengembangkan keberagamaan yang multikultural sebenarnya adalah pendidikan. Sayang, aspek pendidikan multikultural selama ini kurang tersentuh, karena hanya dipandang sebagai persoalan pinggiran yang tidak signifikan. Padahal pendidikan dalam pengertian umum sebagai basis atau dasar untuk menciptakan SDM dan pembentukan karakter suatu bangsa. Pendidikan sebagaimana ditegaskan Ahmad Syafi'i Ma'arif, sesungguhnya juga wahana paling efektif untuk internalisasi nilai-nilai demokrasi, pluralisme, dan inklusivisme. Pendidikan di Indonesia selama orde baru, hanya sebagai proses pemenuhan kewajiban yang cenderung bersifat proyek instan, sehingga yang terjadi hanya sekedar pembentukan manusia yang siap kerja dan menjadi pegawai. Era orde baru, pendidikan hanya disamakan dengan pengajaran; aspek pembentukan sikap, kepribadian, mental, dan kreativitas jauh dari jangkauan pendidikan. Hasil pendidikan model orde baru tidak mengajarkan atau bahkan menjauhi sikap keberagamaan yang multikultural. Ketika itu yang diajarkan justru menumbuhkan sikap kebenaran dan pembelaan pada agamanya sendiri (Fanani, 2004).

Menyimak pendidikan agama Islam di Indonesia. Materi pembelajaran memang lebih ditekankan pada persoalan teologis-normatif yang banyak dijumpai dalam mata pelajaran Fikih, Alquran dan Hadis, Akhlak, serta mata pelajaran lainnya. Sedangkan orientasi kekinian kurang mendapat respon, seperti demokratisasi, hak asasi manusia, budaya kerja, menerima peradaban, menghargai pluralitas, multukultural dan sebagainya. Di samping itu, menjadi pertanyaan melihat pengaplikasian nilai-nilai agama yang masih rendah di kalangan peserta didik yang kemudian menjadi bagian terpenting dalam kehidupan masyarakat. Setidaknya, masih banyak kelemahan dalam 
mengeksekusi kurikulum tersebut khususnya dalam isi kurikulum pendidikan agama Islam. Konsep tentang pluralitas masih sangat kurang bahkan hampir tidak ada. Kurikulum agama hanya berisikan materi ibadah ubudiyah atau praktek-praktek keagamaan lainnya yang mengatur manusia dalam hubungan dengan Tuhannya (hablun min Allah), sehingga materi tentang hubungan mereka dengan sesama manusia (hablun min alnas), khususnya dengan yang berbeda keyakinan (perbedaan mazhab, teologi, dan sebagainya) menjadi kurang (Salim, 2012).

Materi pelajaran agama di bangku sekolah atau madrasah tentang ide kemajemukan dan kerukunan memang masih sangat minim. Pelajaran seperti ini malah lebih banyak ditemukan di mata pelajaran sejarah, pendidikan kewarganegaraan, maupun geografi, bahwa bangsa ini terdiri dari berbagai jenis suku, ras, bahasa, dan agama adalah sebuah kenyataan sosial yang tidak bisa terbantahkan. Agama sendiri menjadi pilar dasar kebangsaan Indonesia. Meskipun dalam sebuah negara demokrasi presidensial, akan tetapi nafas agama senantiasa tidak bisa dihilangkan. Dalam sila pertama Pancasila menunjukkan peran agama dalam konstitusi negara, yakni Ketuhanan Yang Maha Esa. Hal ini tidak bisa dipisahkan dari sebuah fakta sosial bahwa di Indonesia sendiri maupun sistem kepercayaan yang hadir dari luar. Dalam sejarah pendidikan pluralitas sebagai sebuah konsep atau pemikiran tidak muncul dalam ruangan yang kosong, namun ada interes politik, sosial, ekonomi, dan intelektual yang mendorong kemunculannya. Wacana pendidikan multikultural pada awalnya sangat dekat dengan negara adidaya yaitu Amerika Serikat, karena pendidikan multikultural memiliki akar sejarah dengan gerakan Hak Asasi Manusia (HAM) dari berbagai kelompok yang tertindas di negeri tersebut. Banyak uraian sejarah ataupun asal-usul pendidikan multikultural yang merujuk pada gerakan sosial orang Amerika keturunan Afrika dan kelompok kulit warna lain yang mengalami praktek diskriminasi di lembaga lembaga publik. Di antara lembaga-lembaga tersebut adalah lembaga pendidikan. Sekitar tahun 1960- an sampai 1970-an, suara-suara yang menuntut agar lembaga pendidikan lebih konsisten dalam menerima dan menghargai perbedaan semakin kencang. Mereka menuntut adanya persamaan kesempatan di bidang pekerjaan dan pendidikan. Momentum inilah yang dianggap sebagai awal mula dari konseptualisasi pendidikan multikultural (Suardi, 2015).

Konsep pendidikan multikultural dalam perjalanannya mulai melebarkan sayapnya, ketika kelompok kawasan yang secara khusus memiliki keragaman etnis, ras, agama, dan budaya seperti halnya Indonesia. Sekarang ini, pendidikan multikultural secara umum mencakup ide pluralisme dan multikulturalisme. Tema umum yang dibahas meliputi pemahaman budaya, penghargaan budaya dari kelompok yang beragam dan persiapan untuk hidup dalam masyarakat multikultural. Dalam konteks ke-Indonesiaan, pendidikan multikultural mendapat apresiasi dari berbagai kalangan seiring dengan 
keruntuhan rezim Soeharto. Ihwal pluralisme dan multikulturalisme sudah saatnya dikampanyekan dan tidak hanya berhenti pada tataran wacana dan sering menjadi komoditas politik, melainkan lebih dari itu, nilai-nilai pluralisme seharusnya dilanjutkan pada pembebasan (liberasi) terhadap segala bentuk kezaliman, ketidakadilan, status quo, dan politisasi rakyat kecil yang perlu segera disusun menjadi agenda aksi nyata dan membebaskan pada jenjang pendidikan termasuk di Madrasah Aliyah.

\section{Konsep Pendidikan Multikultural}

Pembumian wacana multikulturalisme pada ranah pendidikan formal (sekolah) dewasa ini semakin menggeliat. Maraknya gagasan multikulturalisme disertai dengan penyebaran isu pendahuluan, banyaknya peristiwa bentrokan dan konflik horizontal di tengah masyarakat. Berbagai pihak kemudian menyuarakan gagasan ini lebih keras dan diimplementasikan lebih dini dalam kurikulum pendidikan. Akar pendidikan multikultural, berasal dari perhatian seorang pakar pendidikan Amerika Serikat Prudence Crandall (18-3-1890) yang secara intensif menyebarkan pandangan tentang arti penting latar belakang peserta didik, baik ditinjau dari aspek budaya, etnis, dan agamanya. Pendidikan yang memperhatikan secara sungguh-sungguh latar belakang peserta didik merupakan cikal bakal bagi munculnya pendidikan multikultural. Konsep pendidikan multikultural dalam perjalanannya menyebar luas ke kawasan di luar AS khususnya di negara-negara yang memiliki keragaman etnis, rasionalisme, agama dan budaya seperti di Indonesia. Sedangkan wacana tentang pendidikan multikultural, secara sederhana dapat didefenisikan sebagai "pendidikan untuk/tentang keragaman kebudayaan dalam merespon perubahan demografis dan kultural lingkungan masyarakat tertentu atau bahkan dunia secara keseluruhan". (Lasijan, 2014)

Mengenai fokus pendidikan multikultural, Tilaar mengungkapkan bahwa dalam program pendidikan multikultural, fokus tidak lagi diarahkan semata-mata kepada kelompok rasial, agama dan kultural domain atau mainstream. Fokus seperti ini pernah menjadi tekanan pada pendidikan interkultural yang menekankan peningkatan pemahaman dan toleransi individu-individu yang berasal dari kelompok minoritas terhadap budaya mainstream yang dominan, yang pada akhirnya menyebabkan orang-orang dari kelompok minoritas terintegrasi ke dalam masyarakat mainstream. Pendidikan multikultural sebenarnya merupakan sikap "peduli" dan mau mengerti (difference), atau "politics of recognition" politik pengakuan terhadap orangorang dari kelompok minoritas. (Tilaar, 20013)

Selanjutnya James Bank, salah seorang pioner dari pendidikan multikultural dan telah membumikan konsep pendidikan multikultural menjadi ide persamaan pendidikan mengatakan bahwa substansi pendidikan multikultural adalah pendidikan untuk kebebasan (as education for freedom) sekaligus sebagai penyebarluasan gerakan inklusif dalam rangka mempererat 
hubungan antar sesama (as inclusive and cementing movement). Pendidikan multikultural adalah merupakan suatu wacana yang lintas batas, karena terkait dengan masalah-masalah keadilan sosial (social justice), demokarasi dan hak asasi manusia. (Tilaar, 2003)

Azyumardi azra mendefinisikan pendidikan multikultural sebagai pendidikan untuk atau tentang keragaman kebudayaan dalam merespon perubahan demografi dan kultur lingkungan masyarakat tertentu atau bahkan demi secara keseluruhan. (Imron, 2009) H.A.R.Tilaar menyatakan bahwa model pendidikan yang dibutuhkan di Indonesia harus memperhatikan enam hal, yaitu : pertama, pendidikan multikultural haruslah berdimensi "right to culture" dan identitas lokal. Kedua, kebudayaan Indonesia yang menjadi, artinya kebudayaan Indonesia merupakan weltanshaung yang terus berprosers dan merupakan bagian integral dari proses kebudayaan mikro, maka perlu mengoptimalkan budaya lokal yang beriringan dengan apresiasi terhadap budaya nasional. Ketiga, pendidikan multikultural normatif, yaitu model pendidikan yang memperkuat identitas nasional yang terus menjadi tanpa harus menghilangkan identitas budaya lokal yang ada. Keempat pendidikan multikultural merupakan suatu rekonstruksi sosial, artinya pendidikan multikultural tidak boleh terjebak pada xenophobia, fanatisme dan fundamentalisme, baik etnik, suku maupun agama. Kelima, pendidikan multikultural merupakan pedagogik pemberdayaan (pedagogy of empowerment) dan pedagogik kesetraan (pedogogy of equity). Pedagogik pemberdayaan berarti seseorang diajak mengenal budayanya sendiri dan selanjutnya digunakan untuk mengembangkan budaya Indonesia di dalam bingkai negara-bangsa Indonesia. Dalam upaya ini diperlukan suatu pedagogik kesetaraan antar individu, suku, agama dan beragam perbedaan yang ada. Keenam, pendidikan multikultural bertujuan mewujudkan visi Indonesia masa depan serta etika bangsa. Pendidikan ini perlu dilakukan untuk mengembangkan prinsip-prinsip etis (moral) masyarakat Indonesia yang dipahami oleh keseluruhan komponen sosial-budaya yang plural. (Tilaar, 20013).

\section{Prinsip-Prinsip Pendidikan Multikultural}

Memperbincangkan diskursus pemikiran pendidikan selalu menarik perhatian bagi semua kalangan, utamanya para stakeholder pendidikan. Sebab, tema dan pendekatan yang dilakukan sangat beragam. Salah satunya adalah pendidikan dengan multikulturalisme, yang melahirkan konsep pendidikan multikultural. Choirul Mahfud menjelaskan bahwa, Wacana pendidikan multikultural ini dimaksudkan untuk merespon fenomena konflik etnis, sosial, budaya yang kerapmuncul ditengah-tengah masyarakat yang berwajah multikultural. Wajah multikultural di negeri ini hingga kini ibarat api dalam sekam, yang suatu saat bisa muncul akibat suhu politik, agama, sosial budaya yang memanas, yang memungkinkan konflik tersebut muncul kembali. Tentu 
penyebab konflik banyak sekali tetapi kebanyakan disebabkan oleh perbedaan politik, suku, agama, ras, etnis dan budaya. Beberapa kasus yang pernah terjadi di tanah air yang melibatkan kelompok masyarakat, mahasiswa bahkan pelajar karena perbedaan pandangan sosial politik atau perbedaan SARA tersebut. (Mahfud, 2009)

Jelas bahwa menurut A. Fuad Fanani, unsur utama dalam pendidikan multikultural adalah penempatan posisi siswa sebagai subyek yang bersifat sejajar. Tidak ada superioritas satu komponen kultural seorang siswa terhadap siswa lainnya. Maka pendidikan multikultural ini dapat melatih dan membangun karakter siswa mampu bersikap demokratis, humanis dan pluralis dalam lingkungan mereka. Pendidikan multikultural memiliki posisi strategis dalam memberikan sumbangsih terhadap penciptaan perdamaian dan upaya penanggulangan konflik. Sebab nilai-nilai dasar dari pendidikan ini adalah penanaman dan pembumian nilai toleransi, empati, simpati dan solidaritas sosial. (Fanani, 2004)

Calarry Sada dengan mengutip tulisan Sleeter dan Grant, menjelaskan bahwa pendidikan multikultural memiliki empat makna (model), yakni, (1) pengajaran tentang keragaman budaya sebuah pendekatan asimilasi kultural, (2) pengajaran tentang berbagai pendekatan dalam tata hubungan sosial, (3) pengajaran untuk memajukan pluralisme tanpa membedakan strata sosial dalam masyarakat, dan (4) pengajaran tentang refleksi keragaman untuk meningkatkan pluralisme dan kesamaan. Sebagai suatu gerakan pembaharuan dan proses untuk menciptakan lingkungan pendidikan yang setara untuk seluruh siswa, pendidikan multikultural memiliki prinsip-prinsip sebagai berikut :

Prinsip pertama, pendidikan multikultural adalah gerakan politik yang bertujuan menjamin keadilan sosial bagi seluruh warga masyarakat tanpa memandang latar belakang yang ada.

Prinsip kedua, pendidikan multikultural mengandung dua dimensi: pembelajaran (kelas) dan kelembagaan (sekolah) dan antara keduaanya tidak bias dipisahkan, tetapi justru harus ditangani lewat reformasi yang komprehensif.

Prinsip ketiga, pendidikan multikultural menekankan reformasi pendidikan yang komprehensif dapat dicapai hanya lewat analisis kritis atas sistem kekuasaan dan privileges untuk dapat dilakukan reformasi komprehensif dalam pendidikan.

Prinsip keempat, berdasarkan analisis kritis ini, maka tujuan pendidikan multikultural adalah menyediakan bagi setiap siswa jaminan memperoleh kesempatan guna mencapai prestasi maksimal sesuai dengan kemampuan yang dimiliki.

Prinsip kelima, pendidikan multikultural adalah pendidikan yang baik untuk seluruh siswa, tanpa memandang latar belakangnya. (Sada, 2004) 
Dalam pandangan Ali Maksum dan Luluk Yunan Ruhendi, ciri-ciri dari pendidikan multikultural adalah : (a) tujuannya membentuk "manusia budaya" dan menciptakan "masyarakat berperadaban" (berbudaya); (b) materinya mengajarkan nilai-nilai luhur kemanusiaan, nilai-nilai bangsa, dan nilai-nilai kelompok etnis (kultural); (c) metodenya demokratis, yang menghargai aspekaspek perbedaan dan keragaman budaya bangsa dan kelompok etnis (multikulturalis), dan; (d) evaluasinya ditentukan pada penilaian terhadap tingkah laku anak didik yang meliputi persepsi, apresiasi, dan tindakan terhadap budaya lainnya. (Maksum, 2004)

Kurikulum dan materi Pendidikan Agama Islam bagaimana pun tidak dapat terlepas dari dimensi perkembangan dan nilai-nilai pendidikan multikultural. Pendidikan Agama Islam yang terintegrasi dengan spirit pendidikan multikultural perlu segera menampilkan ajaran-ajaran Islam yang toleran dengan menitikberatkan pada pemahaman dan upaya untuk bisa hidup dalam konteks perbedaan agama dan budaya, baik secara individual maupun secara kelompok. Oleh karenanya, dalam upaya pengembangan kurikulum pendidikan agama Islam harus diperhatikan dimensi-dimensi berikut ini :

Pertama, pembelajaran fiqih dan tafsir al-Qur'an tidak harus bersifat linier, namun menggunakan pendekatan muqāran (perbandingan). Ini menjadi sangat penting, karena siswa tidak hanya dibekali pengetahuan atau pemahaman tentang ketentuan hokum dalam fiqih atau makna ayat yang tunggal, namun juga diberikan pandangan yang berbeda. Tentunya, bukan sekedar mengetahui yang berbeda, namun juga diberikan pengetahuan (argumen-dalil) tentang mengapa bisa berbeda; kedua, untuk mengembangkan kecerdasan sosial, siswa juga harus diberikan pendidikan lintas agama. Hal ini dapat dilakukan dengan mengadakan dialog antar agama; ketiga, untuk memahami realitas perbedaan dalam beragama, lembaga-lembaga pendidikan Islam menyelenggarakan program road show lintas agama dengan tujuan untuk menanamkan kepedulian dan solidaritas terhadap komunitas agama lain; dan keempat, untuk menanamkan kesadaran spiritual, pendidikan Islam perlu menyelenggarakan program seperti spiritual work camp, yaitu dengan cara mengirimkan siswa untuk tinggal dalam sebuah keluarga selama beberapa hari, termasuk kemungkinan tinggal pada keluarga yang berbeda agama. (Aly, A., 2003)

\section{Relevansi Fikih Siyasah dengan Pendidikan Multikultural}

Pendidikan multikultural sebagai salah satu strategi dalam mewujudkan kebijakan politis dalam keberagaman budaya masyarakat, menurut Azra dapat digunakan baik pada tingkat deskriptif dan normatif, yang menggambarkan isuisu dan masalah-masalah pendidikan yang berkaitan dengan masyarakat multikultural. Dalam konteks deskriptif dan normatif, kurikulum pendidikan multikultural menurutnya harus mencakup subyek-subyek daripada nilai-nilai multiultural seperti: toleransi, tema tema tentang perbedaan ethno-kultural, 
dan agama; bahaya diskriminas; penyelesaian konflik dan mediasi; HAM; demokrasi dan pluralitas; kemanusiaan universal, dan subyek-subyek lain yang relevan. (Azra, 2007)

Multikulturalisme merupakan pengakuan bahwa beberapa kultur local yang berbeda dapat eksis dalam lingkungan yang sama dan me nguntungkan satu sama lain, atau pengakuan dan promosi terhadap pluralisme kultural. Sebagai institusi pembebas, fikih harus dimaknai proses bukan produk monumental. Hukum Islam atau fikih, memiliki karakteristik yang jauh berbeda dengan hukum dalam pengertian ilmu hukum modern. Hukum Islam dikembangkan berdasarkan wahyu di samping pemikiran manusia, yang memuat aspek lokalitas kultural dan universalitas. Dengan demikian, fikih dikatakan sebagai hasil akhir dari suatu proses dialogis dan dialektis antara pesan-pesan samawi (normativitas) dengan kondisi aktual bumi (historisitas). Aturan-aturan yang terbukukan dalam berbagai kitab fikih tidak dapat dilepaskan dari pengaruh cara pandang manusia, baik secara pribadi maupun sosial. Dengan demikian, selain sarat dengan nilai teologis, fikih juga memiliki watak sosiologis. (Tahir, 2004)

Ada beberapa bukti kesejarahan lainnya untuk menunjukkan bagaimana kondisi sosial budaya memberikan pengaruh kuat terhadap pembentukan fikih. Adanya qaul jadîd dari Imam Syâfi'i yang dikompilasikan setelah sampainya ia di Mesir, ketika dikontraskan dengan qaul qadîm-nya yang dikompilasikan di Irak, merefleksikan adanya pengaruh dari tradisi adat kedua negeri yang berbeda. Imam Mâlik percaya bahwa aturan adat dari suatu negeri harus dipertimbangkan dalam memformulasikan suatu ketetapan, walaupun ia memandang adat ahl al-Madînah sebagai variabel yang paling otoritatif dalam teori hukumnya, merupakan bukti lain dari kuatnya pengaruh kultur setempat tidak pernah dikesampingkan oleh para juris muslim dalam usahanya untuk membangun hokum. (Lukito, 1998)

Fenomena yang disebut terakhir ini menunjukkan bahwa fikih Islam adalah hukum yang hidup dan berkembang, mampu bergumul dengan persoalan-persoalan lokal yang senantiasa meminta etik dan paradigm baru. Keluasan hukum Islam adalah satu bukti dari adanya ruang gerak dinamis itu. Ia merupakan implementasi obyektif dari doktrin Islam yang meskipun berdiri di atas kebenaran mutlak dan kokoh, juga memiliki ruang gerak dinamis bagi perkembangan, pembaharuan dan kehidupan sesuai dengan fleksibilitas ruang dan waktu.

Berdasarkan pembahasan di atas kita akan menemukan relevansi Fikih Siyasah (Hukum Ketatanegaraan Islam) dengan pendidikan multikultural sesuai dengan tujuan Pendidikan Islam yaitu :

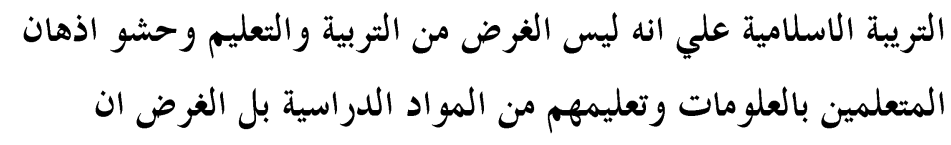




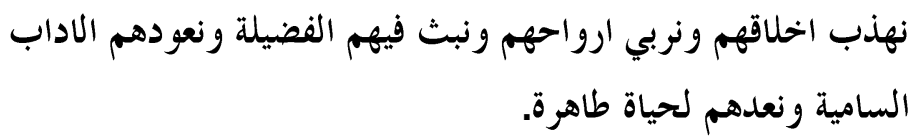

Tujuan pendidikan Islam bukan sebatas mengisi pikiran siswa dengan ilmu pengetahuan dan materi pelajaran akan tetapi membersihkan jiwanya yang harus diisi dengan akhlak dan nilai-nilai yang baik dan dikondisikan supaya biasa menjalani hidup dengan baik. (Al-Abrasyi, 1969).

Dari tujuan pendidikan Islam tersebut, dapat disimpulkan bahwa siswa diharapkan dapat menjadi manusia yang berakhlak mulia dan dapat menghargai keragaman budaya di sekitarnya. Hal tersebut senada dengan prinsip yang ada dalam pendidikan multikultural. Dalam literatur pendidikan Islam, Islam sangat menaruh perhatian (concern) terhadap segala budaya dan tradisi ('urf) yang berlaku di kalangan umat manusia dalam setiap waktu dan kondisi, baik yang bersifat umum atau hanya berlaku dalam satu komonitas. Hal ini dapat dibuktikan dengan banyaknya ketetapan-ketetapan dalam Islam yang berdasarkan 'urf yang berlaku. Sabda Rasulullah SAW yang dijadikan sebagai salah satu dalil dari bentuk concern Islam terhadap 'urf adalah:

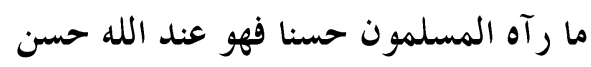

"apa yang dianggap baik oleh kaum muslimin, maka hal itupun merupakan kebaikan menurut Allah" (HR. Ahmad). (Ibrahim, 2013)

Pendidikan Multikultural juga senada dengan tujuan agama yang berbunyi: "Tujuan umum syari'ah Islam adalah mewujudkan kepentingan umum melalui perlindungan dan jaminan kebutuhan-kebutuhan dasar (aldaruriyyah) serta pemenuhan kepentingan (al-hajiyyat) dan penghiasan (tahsiniyyah) mereka." (Khalaf, 1978) Dari konsep inilah kemudian tercipta sebuah konsep al-daruriyyah al-khamsah (lima dasar kebutuhan manusia), yang meliputi jiwa (al-nafs), akal (al-aql), kehormatan (al-irdh), harta benda (al-mal), dan agama (al-din). (Abdillah, 1999)

Sebagaimana dikemukakan Abu Ishak al-Syatibi, dalam kutipan Saidani dengan perincian sebagai berikut :

a. Memelihara Agama

Agama sesuatu yang harus dimiliki oleh setiap manusia, supaya derajatnya terangkat dan memenuhi hajat jiwanya. Agama Islam harus terpelihara dari ancaman orang yang akan merusak akidah, syari'ah dan akhlak atu mencampuradukkan ajaran agama Islam dengan faham atau aliran yang batil. Agama Islammemberikan perlindungan kepada pemeluk agama lain untuk menjalankan agama sesuai dengan keyakinannya dan tidak memaksakan pemeluk agama lain meninggalkan agamanya untuk memeluk Islam (QS. 2: 256).

b. Memelihara Jiwa

Jiwa harus dilindungi, untuk itu hukum Islam wajib memelihara hak manusia untuk hidup dan mempertahankan hidupnya, dan dilarang melakukan sesuatu yang dapat menghilangkan jiwa manusia dan melindungi berbagai 
sarana yang digunakan oleh manusia untuk mempertahankan kemaslahatan hidupnya.

c. Memelihara akal

Memelihara akal adalah wajib hukumnya bagi seseorang, karena akal mempunyai peranan sangat penting dalam hidup dan kehidupan manusia. Dengan akal, manusia dapat mengembangkan ilmu pengetahuan dan teknologi. Seseorang tidak akan mampu menjalankan hukum Islam dengan baik dan benar tanpa menggunakan akal yang sehat. Oleh karena itu Islam melarang orang meminum-minuman khamr39, karena akan merusak akal. Sebagaimana dijelaskan dalam QS. Al-Maidah: 90.

d. Memelihara Keturunan

Dalam Islam, memelihara keturunan hal yang sangat penting. Untuk itu harus ada perkawinan yang dilakukan secara sah menurut ketentuan yang berlaku yang ada dalam al-Qur'an dan sunnah nabi dan dilarang melakukan perbuatan Zina. Hukum kekeluargaan dan kewarisan Islam dalam al-Qur'an merupakan hukum yang erat kaitannya dengan pemurnian keturunan dan pemeliharaan keturunan. Pemeliharaan keturunan berkaitan dengan perkawinan dan kewarisan disebutkan secara rinci dan tegas misalnya larangan-larangan perkawinan (QS. An-Nisa ayat 23) dan larangan berzina (QS. Al-Isra ayat 32).

e. Memelihara Harta

Menurut hukum Islam, harta merupakan pemberian Allah kepada manusia untuk kesejahteraan hidup dan kehidupannya, untuk itu manusia sebagai khalifah (human duties) Allah di muka bumi diberi amanah untuk menglola alam ini sesuai kemampuan yang dimilikinya, dilindungi haknya untuk memperoleh harta dengan cara yang halal, sah menurut hukum dan benar menurut ukuran moral, dan dipergunakan secara sosial. (Haryono, 1968)

Menjamin keamanan dari kebutuhan-kebutuhan hidup merupakan tujuan pertama dan utama dari pendidikan Islam. Dalam kehidupan manusia, ini merupakan hal penting, sehingga tidak bisa dipisahkan. Apabila kebutuhan ini tidak terjamin, akan terjadi kekacauan di mana-mana. Kelima kebutuhan yang primer ini disebut dengan istilah Al-Daruriyat al-Khamsah atau dalam kepustakaan hukum Islam disebut dengan istilah al-Maqasid al-Khamsah, yaitu: agama, jiwa, akal pikiran, keturunan, dan hak milik.

Jika diperhatikan dengan seksama, tujuan pendidikan Islam ditetapkan oleh Allah untuk memenuhi keperluan hidup manusia itu sendiri, baik keperluan primer (al-maqasidu al-khamsah), sekunder (hajiyat) , dan tertier (tahsinat). (Praja, 1988)

\section{Pendidikan Multikultural dalam Piagam Madinah ditinjau dari Fikih Siyasah}

Hijrah Nabi muhammad saw ke Madinah pada tahun 622 M merupakan era baru dalam usaha beliau dalam mengefektifkan dakwah Islam, karena di kota ini beliau telah memperoleh dukungan kuat dari warganya. Dukungan 
tersebut tidak beliau peroleh secara tiba-tiba, melainkan tumbuh dengan perlahan-lahan yang diawali dengan kesepakatan mereka dengan beliau ketika masih berada di Mekkah. Namun, dukungan tersebut belum membuat posisi beliau benar-benar mantap. Karena penduduk Madinah menurut pembagian genealogi maupun etnis dan keyakinan terbagi ke dalam beberapa kelompok sosial yang saling berbeda dalam cara berpikir dan kepentingan . untuk itu beliau membuat perjanjian tertulis yang dapat diterima oleh semua kelompok sosial yang bercorak mejemuk itu. (Pulungan, 1994)

Nabi memandang perlunya sebuah persaudaraan yang dapat memperkuat Madinah sebagai kota yang didiami oleh berbagai kelompok agama dan suku. Merekapun menyepakati agar tidak ada gangguan dari pihakpihak luar, khususnya kalangan pagan Quraisy Mekkah yang masih ingin memperlakukan umat Islam secara tidak manusiawi. Maka dari itu, dicetuskan sebuah piagam yang menyemangati kehidupan yang damai dan membela kedaulatan Madinah dari ancaman pihak luar. (Misrawi, 2009)

Karena itu hati Nabi tergerak untuk lebih menyempurnakan ikatan sosial dalam tubuh negara Madinah. Dengan terperinci disampaikan hak dan kewajiban setiap kelompok, agar perselisihan baru tidak menyebar tanpa petunjuk penyelesaian, dibuatlah undang-undang sehingga menjadi pedoman para pemegang kekuasaan dalam mengambil keputusan, dan menjadi payung hukum bila mereka dipersalahkan. Nabi memerintahkan agar undang-undang menyangkut kaum Muhajirin, Anshar, dan Yahudi ini ditulis secara jelas, transparan, dan detail. Ini adalah undang-undang pertama bagi sebuah negara berperadaban dalam arti modern, undang-undang Madinah yang baru tumbuh. (Abazhah, 2017)

Piagam Madinah adalah sebuah piagam yang dianggap banyak pihak sebagai sebuah pencapaian spektakuler, karena mampu membuat sebuah kesepakatan diantara berbagai pihak yang selama ini tidak mungkin dipersatukan. Nabi semakin dikenal sebagai pihak yang merekatkan diantara berbagai kelompok, yang membuat namanya begitu harum di Jazirah Arab. (Misrawi, 2009)

Piagam tersebut telah menjadi inspirasi bagi banyak kalangan untuk membangun harmonisasi dan toleransi. Dalam masyarakat yang multikultural dan majemuk, piagam tersebut merupakan inspirasi agar kemajemukan menjadi kekuatan, alih-alih kelemahan. (Taqiyudin, 2009)

Dengan demikian, Piagam Madinah ini merupakan kontrak politik pertama dalam arti yang sesungguhnya. Dalam Piagam tersebut Nabi berhasil menempatkan dua kelompok Aus dan Khazraj dalam satu nota kesepakatan untuk hidup berdampingan secara damai dan membangun hubungan ekonomi yang sehat. Suku-suku Madinah dan kaum Yahudipun dirangkul tanpa ada yang tertinggal. Tidak dibenarkan menyulut api permusuhan diantara seluruh peserta nota kesepakatan tersebut. Sebaliknya, mereka harus hidup dalam semangat solidaritas dan kerjasama yang kuat untuk menghadapi setiap 
ancaman dari luar, serta berjanji untuk merapatkan barisan pertahan. (Abazhah, 2017)

Piagam Madinah merupakan dokumen yang sarat dengan nilai-nilai dasar etika politik itu, mencantumkan dua prinsip pokok yaitu hak dan kewajiban asasi warga negara serta hubungan antar negara dengan warga negara. Warga negara dalam Piagam Madinah itu meliputi muslim (Muhajirin dan Anshar) dan nonmuslim (Yahudi). (Susmihara, 2015)

Dengan adanya Piagam Madinah, orang-orang Yahudi dan orang-orang Mukmin kemudian bersatu. Penduduk Madinah yang majemukpun menjadi masyarakat yang teratur, dapat hidup bersama dan bekerja sama dalam satu wilayah untuk mencapai tujuan bersama. (Pulungan, 1994) Masyarakat hidup akur, kompak, dan harmonis. Setiap rumah nyaman dihuni, tak ada yang merasa asing. Tak ada keunggulan ras dan asal-usul. Tak ada yang merasa berkedudukan lebih tinggi. Tak ada yang berharta lebih berlimpah. Sikap arogansi, tinggi hati, merasa lebih terhormat, dan segala hal yang berbau Jahiliah telah ditinggalkan. (Abazhah, 2017)

Berdasarkan perjalanan sejarah Piagam Madinah sebagaimana pembahasan di atas, setidaknya dapat disimpulkan mengandung nilai-nilai Pendidikan Multikultural yakni Pertama, Piagam Madinah mengakui hak kebebasan beragama serta kebebasan berpendapat. Kedua, menjunjung tinnggi sikap toleran terhadap pluralitas suku, agama dan ras. Ketiga, Piagam Madinah memberikan persamaan asasi berupa persamaan dalam hak dan kewajiban bagi kaum muslim dan non-muslim dalam bidang sosial dan politik, serta mampu memberikan rasa aman bagi semua pihak yang terkait di dalamnya.

\section{Paradigma Fikih Siyasah (Politik Islam) terhadap Pendidikan Multikultural}

Pendidikan multikultural merupakan salah satu alternatif yang menawarkan penerapan strategi dan konsep pendidikan yang berbasis pada pemanfaatan keragaman yang ada di masyarakat seperti keragaman etnis, budaya, bahasa, ajaran agama, status sosial, gender, kemampuan, umur, dan sebagainya. Lebih dari itu, dalam pendidikan multikultural juga diharapkan mampu menanamkan nilai-nilai yang menjadi karakter intinya seperti demokrasi, humanisme, dan pluralisme atau menanamkan nila-inilai keberagamaan yang inklusif, toleran dan peduli dalam pencegahan terhadap terjadinya tindak kekerasan dan konflik komunal di tengah masyarakat yang serba plural. Dengan demikian, pada gilirannya output yang dihasilkan dari corak pendidikan ini tidak hanya cakap sesuai dengan disiplin ilmu yang ditekuninya, tetapi juga mampu menerapkan nilai-nilai keberagamaan dan menghargai keberadaan pemeluk atau penganut aliran keagamaan yang tidak sepaham dengan yang diikutinya.

Dalam setiap agama, teologi sebagai 'konsep kepercayaan' tidak bias dilepaskan sebagai dasar pijakan bagi setiap pemeluknya. Pembicaraan tentang konsep ini lebih dikarenakan bahwa kepercayaan dan keyakinan adalah inti 
agama. Dalam ruang lingkup Islam, persoalan yang berkenaan dengan konsep kepercayaan sangat penting tidak saja karena masalah tersebut berkenaan dengan esensi dan eksistensi Islam sebagai suatu agama, tetapi hal ini juga karena menjadi titik awal dari semua pemikiran teologik di antara para pendahulu Islam. (Izutsu, 1994)

Paradigma politik Islam dalam pendidikan multikultural dengan melalui dialog teologis antar agama-agama menurut Islam sangat mungkin dapat dicapai karena adanya landasan yang kuat dalam al-Qur'an. Menurut Maksum, al-Qur'an setidaknya telah menggagas empat prinsip yang menyangkut titik temu agama-agama, yaitu: Pertama, hakikat agama adalah agama Tuhan, yakni suatu ajaran yang telah diturunkan kepada para Nabi dan Rasul, walaupun tiaptiap kurun dari mereka membawa syari'ah dan minhaj (jalan) yang berbedabeda, seperti disebut dalam QS. Al-Maidah : 48. Kedua, agama para Nabi dan Rasul adalah satu, dan agama Islam yang dibawa oleh Muhammad SAW adalah agama terakhir yang merupakan kelanjutan agama-agama sebelumnya. Misi Muhammad sebagai kelanjutan daripada agama sebelumnya ini seperti yang disebutkan dalam QS. Al-Syura : 13. Ketiga, bahwa seorang Muslim tidak boleh berdebat melainkan dengan cara-cara yang paling baik, mencerca dan menghina orang lain di luar agamanya kecuali dilakukan terhadap mereka yang zalim dan bersifat agresif. Larangan untuk tidak berbuat demikian ini seperti disinggung dalam QS. al-Ankabut : 46. Keempat, al-Qur'an mengajarkan sikap inklusif dalam beragama, yakni Islam melarang adanya paksaan terhadap keberagamaan seseorang. Allah telah memberikan kekebasan kepada setiap manusia untuk memilih agama sesuai dengan keinginan yang diyakininya dalam QS. Yunus: 99. (Maksum, 2011)

Pada bangsa yang beragam yang terdiri dari berbagai macam agama dan aliran keagamaan, seperti diungkapkan oleh Suprayogo, masingmasing pengikut agama dan aliran keagamaan boleh-boleh saja mereka merasa benar, dan memang seharusnya demikian. Akan tetapi pada saat yang sama setiap dari mereka tidaklah dapat menganggap yang lainnya adalah sesat, karena tuduhan tersebut sejatinya dalam konteks beragama merupakan hak mutlak yang hanya dimiliki oleh Tuhan. Posisi manusia adalah sama, yaitu masing-masing harus didudukkan sebagai hamba yang berjalan menuju keridlaannya. Siapa di antara mereka dan siapa pula yang gagal untuk mendapatkannya, tidak seorang pun yang tahu kecuali Tuhan sendiri. Saling menganggap bahwa yang lain salah, tertolak, dan bahkan sesat selain mengganggu perasaan dan mendatangkan kemarahan, hal ini juga akan mengganggu bangunan persatuan dan kesatuan, sementara bangunan persatuan itu sendiri mempersayaratkan adanya kesanggupan untuk menjaga dan memelihara hati serta perasaan dari pihak masingmasing yang berbeda. Kepercayaan dan keyakinan tidak boleh dipaksakan.

Dalam Islam, selain perbedaan yang ada pada umat manusia adalah bagian daripada sunnatullāh yang tidak dapat dihindari, Nabi pun pada masa 
hidupnya dahulu dalam menyikapi perbedaan keyakinan umatnya juga tidak pernah memaksakannya. Nabi dalam konteks hidup bermayarakat yang beragam dan menjaga persatuan dan kesatuan umat manusia lebih menyeru kepada penegakan keadilan.42 Seruan demikian ini secara jelas dinyatakan Allah dalam berbagai ayat seperti halnya pada QS. al-Baqarah : 256 dan QS. AsySyūra: 15. (Suprayoga, 2013)

\section{Tantangan Pendidikan Multikultural}

Dengan berbagai realitas sebagaimana dijelaskan di atas maka kita akan menemukan sejumlah tantangan dalam merealisasikan Pendidikan Multikultral, khususnya di Indonesia. Problematika dan tantangan pendidikan berwawasan multikultural bila ditelusuri lebih jauh, persoalannya ternyata sangat kompleks. Tantangan yang acapkali ditemukan antara lain ; (1) Globalisasi. Globalisasi tidak disangkal lagi, telah menghasilkan perubahanperubahan mendasar dalam kehidupan manusia baik secara langsung maupun tidak langsung, (2) Gerakan radikalisme Islam. Gerakan radikalisme juga menjadi ancaman tersendiri bagi penyebaran multikulturalisme di dunia. Hal ini dikarenakan pihak-pihak tertentu yang tidak menghendaki kebebasan dan kemajemukan, dengan mempertahankan eksistensi dan ortodoksi agama sembari menempuh jalan kekerasan, (3) Dinamika kelompok dan agama. Konflik dan kerusuhan yang terjadi di beberapa kawasan seperti Aceh, Sampit, Poso, Ambon, tragedi 1988, tragedi Semanggi, serta beberapa konflik yang sering terjadi karena kemajemukan bangsa telah menjadi persoalan kebangsaan yang tak pernah surut dari sejarah Indonesia, (4) Hubungan Agama dan Negara. Ada tiga pandangan hubungan agama dan negara yang sering menjadi perdebatan di masyarakat dan secara khusus di dunia Islam. Pertama Paradigma integralistik. Agama dan negara adalah satu kesatuan yang tidak dapat dipisahkan (integrated). Wilayah agama juga wilayah politik, Kedua Paradigma simbiotik. Agama dan negara berhubungan secara simbiotik atau timbal balik dan saling memerlukan. Agama memerlukan negara, karena dengan negara agama bisa berkembang. Negara memerlukan agama, karena dengan agama negara bisa berkembang dalam hubungan etika dan moral, Ketiga Paradigma sekularistik. Suatu pandangan yang memisahkan antara agama dan negara, agama dan negara dalam paradigma ini, merupakan dua entitas yang berbeda dan tidak mungkin disatukan. (Aly, N. D., 2015).

Dalam sudut pandang yang, tantangan pendidikan multikultural akan ditemukan sebagai berikut :

Pertama, persoalan makna istilah. Multikulturalisme memiliki rentang definisi yang beragam mulai dari sekedar pengakuan terhadap realitas multikultural masyarakat dunia saat ini; upaya untuk menerima dan menghormati realitas itu; hingga pada pengertian yang merefleksikan relativisme kebenaran dan relativisme agama. 
Kedua, kekeliruan memahami agama Islam. Konsep multikulturalisme mendudukan Islam sebagai agama yang sama dan sederajat dengan agama yang lain. Padahal Islam sebagai agama (ad-din) berbeda dengan agama-agama yang ada di dunia ini. Islam adalah satu-satunya agama wahyu yang sampai sekarang orisinalitasnya terjaga.

Ketiga, kekeliruan memahami konsep-konsep penting dalam agama. Pemahaman keliru ini berimbas pada sikap yang tidak tepat dalam mengatasi berbagai problema di masyarakat terkait kehidupan beragama. Konsep-konsep yang dipahami keliru itu seperti konsep Tuhan, konsep Wahyu (al-Qur'an dan al-Hadits), konsep truth claim (klaim kebenaran agama), toleransi, agama sama dengan budaya, kalimatun sawa, dakwah Islamiyah, dan lain sebagainya.

Keempat, kekeliruan memahami budaya dan kesederajatan. Konsep multikulturalisme tidak dapat disamakan dengan konsep keanekaragaman suku bangsa atau kebudayaan yang menjadi ciri masyarakat majemuk (plural society). Karena multikulturalisme menekankan keanekaragaman kebudayaan dalam kesederajatan.

Kelima, agenda buruk globalisasi. Pendidikan multikulturalisme dalam ranah agama patut diduga merupakan agen taktis untuk memuluskan penjajahan nilai-nilai sekular-liberal di era globalisasi. Nilai-nilai sekularliberal dapat mengikis dan menghancurkan pemikiran dan keimanan umat Islam. Globalisasi bukan hanya melahirkan penjajahan ekonomi tetapi juga penjajahan pemikiran, budaya, nilai dan tradisi. (Nuryadin, 2012)

\section{Kesimpulan}

Dari penjelasan di atas dapat disimpulkan, dalam konteks keIndonesiaan, nampaknya analisis yang dinyatakan oleh Huntington cukup mengena pada masyarakat dan bangsa Indonesia. Bagi Indonesia, era globalisasi tampak lebih sebagai sebuah tantangan ketimbang sebagai berkah. Hal ini dapat dilihat pada kondisi bangsa Indonesia sejak dekade terakhir ini yaitu dengan beragamnya konflik sebagaimana disebutkan di atas. Kondisi ini dapat dimulai dengan melihat 'euforia reformasi' yang diikuti oleh berbagai peristiwa anarkis, pelecehan hukum dan merosotnya moral birokrasi, dan pemerintah, merebaknya kriminalitas, dekadensi moral di tengah masyarakat yang membuat orang apriori terhadap kemauan baik pemerintah, dan meningkatnya pergolakan di aras lokal menyulut perubahan pemikiran dan kesangsian akan masa depan.(Huntington, 2002)

Munculnya sekelompok umat Islam yang menolak adanya sikap pluralisme, multikulturalisme dan toleransi disebabkan karena kurangnya pengetahuan dan wawasan tentang tujuan, semangat, dan esensi ajaran Islam. Sikap ekstrimisme, kekakuan, dan kebekuan berislam, menunjukkan kedangkalan pengetahuan dan wawasan agama dan sosialnya. Dalam hal ini, indikasi dari ektrimisme itu sendiri adalah dengan tidak adanya sikap toleran. (Sulalah, 2011) 
Tantangan pendidikan multikultural akan adanya penolakan dari sekelompok umat Islam yang belum memahami secara utuh makna dari multikulturalisme tersebut. Mereka menganggap keliru konsep Pendidikan Multikultural yang telah digagas.

Dalam sudut pandang fikih siyasah tantangan pendidikan multikultural adalah dari sisi regulasi yang belum ada payung hukumnya secara khusus (spesifik) yang mengatur mengenai konsep pendidikan multikultural yang berorientasi kepada Maqoshidu As-Syari'ah.

\section{DAFTAR PUSTAKA}

Abazhah, N. (2017). Sejarah Madinah (Cetakan I). Jakarta: PT. Serambi Ilmu Semesta.

Abdillah, M. (1999). Demokrasi di Persimpangan Makna: Respons Intelektual Muslim Indonesia terhadap Konsep Demokrasi (1966-1993). PT. Tiara Wacana.

Al-Abrasyi, A. (1969). Athiyyah al-Abrasyi, At-Tarbiyyah al-Islamiyyah wa Falsafatuha. Beirut: Dar Al-Fikr.

Aly, A. (2003). Menggagas Pendidikan Islam Multikultural di Indonesia. Ishraqi, II.

Aly, N. D. (2015). Tantangan Bagi Guru Pendidikan Agama Islam Menerapkan Konsep Pendidikan Agama Berwawasan Multikultural. Zawiyah, 1.

Arikunto, S. (1998). Prosedur Penelitian: Suatu Pendekatan Praktek. Jakarta: Rineka Cipta.

Azra, A. (2007). Merawat Kemajemukan Merawat Indonesia. Yogyakarta: Impulse.

Fanani, A. F. (2004). Islam Mazhab Kritis: Menggagas keberagamaan Liberatif. Jakarta: PT Kompas Media Nusantara.

Haryono, A. (1968). Anwar Haryono, Hukum Islam: Keluasan dan Keadilan. Jakarta: Bulan Bintang.

https://sharingkuliahku.wordpress.comimplementasimultikulturalismedalam-dunia-pendidikan/. (2011).

Huntington, S. P. (2002). Benturan Antar Peradaban. Yogyakarta: Qalam.

Ibrahim, R. (2013). Pendidikan Multikultural: Pengertian, Prinsip, dan Relevansinya dengan Tujuan Pendidikan Islam. ADDIN, 7.

Ihsan, F. (1997). Dasar-Dasar Kependidikan. Jakarta: PT. Rineka Cipta.

Imron, M. (2009). Pendidikan Agama Islam Dalam Persepektif Multikulturalisme. Jakarta: Balai Litbang Agama.

Izutsu, T. T. A. F. H. (1994). The Concept of Belief in Islamic Theology: Asemantical Analysis of Imān and Islām. Yogyakarta: Tiara Wacana.

Kemdikbud. Peraturan Pemerintah RI Nomor 19 Tahun 2005 Tentang Standar Nasional Pendidikan. Jakarta.

Khalaf, A. al-W. (1978). Abd al-Wahhab Khalaf, Ilm Ushul al-Fiqh. Kuwait: Dar Al- 
Qalam.

Lasijan. (2014). Multikulturalisme dalam Pendidikan Islam. TAPIs, 10.

Lukito, R. (1998). Ratno Lukito, Pergumulan Antara Hukum Islam dan Adat di Indonesia. Jakarta: INIS.

Mahfud, C. (2009). Pendidikan Multikultural. Yogyakarta: Pustaka Pelajar.

Maksum, A. (2004). Paradigma Pendidikan Universal di Era Modern dan Post Modern (Mencari "Visi Baru" atas "Realitas Baru"Pendidikan Kita. Yogyakarta: IRCiSoD.

Maksum, A. (2011). Pluralisme dan Multikulturalisme: Paradigma Baru Pendidikan Agama Islam di Indonesia. Malang: Aditya Media.

Mastuhu. (1999). Memberdayakan Sistem Pendidikan Islam. Jakarta: PT. Logos Wacana Ilmu.

Misrawi, Z. (2009). Madinah: Kota Suci, Piagam Madinah, dan teladan Muhammad SAW. (Cetakan I). Jakarta: Kompas Media Nusantara.

Nuryadin, R. (2012). Pendidikan Multikulturalisme Perspektif Islam. Islamia Republika.

Praja, J. S. (1988). Juhaya S. Praja, Epistemologi Hukum Islam (Jakarta: IAIN, 1988. Jakarta: IAIN.

Pulungan, J. S. (1994). Prinsip-Prinsip Pemerintahan dalam Piagam Madinah, ditinjau dari Sudut Pandang Al-Qur'an (Cetakan I). Jakarta: Grafindo Persada.

Sada, C. (2004). Multicultural Education in Kalimantan Barat; an Overview. Multicultural Education in Indonesia and South East Asia, I.

Salim, H. (2012). Menggagas Pendidikan Agama Lintas Sekolah Bercirikhaskan Agama Siswa yang Tidak Seagama. Analis, XII.

Suardi, M. (2015). Ideologi Politik Pendidikan Kontemporer. Yogyakarta: Deepublish.

Sulalah. (2011). Pendidikan Multikultural: Didaktika Nilai-Nilai Universalitas Kebangsaan. Malang: UIN Maliki Press.

Suprayoga, I. (2013). Masyarakat Tanpa Ranking: Membangun Bangsa Bersendi Agama. Jakarta: Elex Media Komputindo.

Susmihara. (2015). Etika Politik dalam Sejarah Islam. Rihlah, III.

Tahir, M. (2004). Paradigma Pemikiran Reaktualisasi Hukum Islam di Indonesia: Sebuah Telaah Historis Politis. Istinbath.

Taqiyudin, A. dkk. (2009). Antara Mekkah dan Madinah (Cetakan I). Jakarta: PT. Gelora Aksara Pratama.

Tilaar, H. A. R. (20013). Multikulturalisme; Tantangan-tantangan Global Masa Depan dalam Pendidikan Nasional. Jakarta: Grassindo.

Tilaar, H. A. R. (2003). Kekusaan Dan Pendidikan Suatu Tinjauan Dan Persepektif Studi Kultural. Indonesia Tera.

Zed, M. (2008). Metode Penelitian Kepustakaan (1 ed.). Jakarta: Yayasan Obor Indonesia. 